\title{
Improving Employee Performance: The Role of OCB Between Personal Trust and Leadership
}

\author{
Ampauleng and Salma Abdullah \\ Prodi Manajemen, STIEM Bongaya, Indonesia \\ Email address: \\ ampauleng@stiem-bongaya.ac.id; Salma.abdullah@stiem-bongaya.ac.id
}

\begin{abstract}
The purpose of this study is to investigate the improvement of employee performance with the role of OCB in mediating the relationship of personal trust and leadership. The sampling method illustrated in this research uses a purposive sampling method, namely the Makassar Main Kesyahbandaran Office employees who have extra motivation as many as 54 people. The analytical tool used is WarpPLS 7. 0. Personal trust has a positive and significant impact on employee performance. After that, leadership does not significantly affect employee performance. Next, personal trust has a positive and meaningful influence on OCB. Then, leadership has a positive and significant influence on OCB. Likewise, OCB has a positive and significant impact on employee performance. After that, personal beliefs have a positive and significant impact on employee performance through OCB. And finally, leadership has a positive and significant impact on employee performance through OCB. The originality of this research applies the principle of "SYAHDU" as the basis for employee performance.
\end{abstract}

Keywords: Trust, leadership, OCB, performance.

\begin{abstract}
Abstrak: Tujuan penelitain ini menginvestigasi peningkatan kinerja pegawai dengan peran OCB dalam memediasi pada hubungan kepercayaan personal dan kepemimpinan. Metode penarikan sampel yang diilustrasi dalam riset ini memakai metode purposive sampling yakni pegawai Kantor Kesyahbandaran Utama Makassar yang mempunyai motivasi ekstra sebanyak 54 orang. Perlengkapan analisis yang digunakan merupakan WarpPLS 7. 0. Kepercayaan personal mempengaruhi positif serta bermakna terhadap kinerja pegawai. Setelah itu, kepemimpinan tidak mempengaruhi signifikan terhadap kinerja pegawai. Berikutnya, kepercayaan personal mempengaruhi positif serta berarti terhadap OCB. Kemudian, kepemimpinan mempengaruhi positif serta signifikan terhadap OCB. Begitupula, OCB mempengaruhi positif serta bermakna terhadap kinerja pegawai. Setelah itu, keyakinan personal mempengaruhi positf serta berarti terhadap kinerja pegawai lewat OCB. Serta terakhir, kepemimpinan mempengaruhi positif serta signfikan terhadap kinerja pegawai lewat OCB. Orginalitas penelitian ini menerapkan prinsip "SYAHDU" sebagai basis kinerja pegawai.
\end{abstract}

Kata kunci: Kepercayaan, kepemimpinan, OCB, kinerja. 


\section{INTRODUCTION}

In essence, the position of the Makassar Main Harbormaster Office is to maintain excellent service that is competitive, reliable, guaranteed, and comfortable. The big goal is to produce good and meaningful performance, including employee performance. Performance and qualified employees are employees who can meet the directions and goals set by the organization. In order to obtain employees, who have good performance and are qualified, it is necessary to implement a performance-based program.

Interestingly, when the Makassar Main Harbormaster Office implemented performance based on "SYAHDU" its performance began to show as expected. That is, the Harbormaster educates intending to improve the safety and security of services. Through the SYAHDU program, all forms of complex dynamics of organizational life within the Makassar Main Harbormaster Office can be resolved properly and produce a different form of behavior or Organizational Citizenship Behavior (OCB). Realizing the SYAHDU program, the extra roles must be good so that employee performance is good too. Therefore, it is interesting to do research.

Employee work behaviors have become the subject of research that has attracted the attention of researchers and academics. Among other things, employee attitudes, various work attitudes are often used to predict the performance of people, groups, or organizations (Bateman and Organ, 1983; Organ, 1988) cited by (Oemar, 2013), such as personal beliefs, leadership, and different positions or OCB. Research by (Hajar and Lubis, 2018) explains that personal beliefs tend to affect employee performance positively. Continuing to be great confident continues to be great employee performance. In contrast to (Eser's, 2012) research, it is stated that personal beliefs do not affect performance. It means that personal beliefs no longer determine employee performance. Leadership also determines employee performance. Next, research by (Hajar et al., 2018) suggests that leadership can encourage employee performance. Continue to be good leadership continues to be great employee performance. However, (Widyatmini and Hakim, 2008) created that good leadership, while low employee performance, will certainly reduce the organization's image. No matter how good the leadership is, if the employee's competence is lacking, the employee's performance will shrink or be below. The construct of employee work attitude that gets much attention from researchers is the attitude of extra work or extra position or OCB that was raised by Organ (1988) if the organizational function is facilitated when employees work beyond the official position requirements that are not explicitly required by job descriptions and the official reward system. This type of employee attitude by (Bateman and Organ, 1983); (Smith et al., 1983) are referred to as different attitudes or extra positions or (OCB).

OCB is an employee attitude that gives a different role for sincerity and awareness of helping others (Lubis, 2015). His passion tends to help others selflessly and not financially oriented but more on social values. The goal is to improve good performance and quality (Damaryanthi and Dewi, 2016). Different roles within the Makassar Main Harbormaster Office often occur in all fields, such as six people in the administration, 30 in sailing safety, 3 in legal status and ship certification, and 15 in guard patrol and investigation areas. All of these fields are oriented towards encouraging excellent service that is competitive, professional, comfortable, and safe, especially the safety aspect. They have strong personal beliefs and can translate leadership orders so that different roles run well. The goal is to 
improve employee performance. Therefore, extra roles have a relationship with employee performance.

OCB has a relationship with trust and leadership. Self-confidence certainly raises personal confidence in what will be done, which is believed to provide significant benefits. Therefore, an employee will try hard to complete the work even though it is not part of an employee's formal work obligations. (Anggraini and Rahardjo's, 2016); (Rahayu, 2017) find that trust contributes to encouraging the role of OCB. Of course, when someone's confidence is higher, a different role in completing the job will be good.

Meanwhile, (Appelbaum et al., 2004) stated that trust has a negative and significant effect on OCB. When trust is too high, which is not followed by sufficient competencies such as knowledge, experience, skills, and work awareness, it will reduce extra employee behavior. In contrast to (Fitrijayanti et al., 2015), trust has no significant effect on OCB. That is, OCB is no longer determined by trust.

OCB is not only determined by the trust but also determined by leadership. It is because a leader's behavior can at least create a harmonious, comfortable, and hopeful working atmosphere so that employees are encouraged to perform OCB behavior. (Robbins and Judge, 2013), cited by (Juniartha et al.,2017), define transformational leaders as leaders who invite and inspire their subordinates to do productive work. (Indra et al., 2016) studies; (Kartini, 2019); (Napitupulu, 2018); (Tjahjono et al., 2018); (Yohannes and Supit, 2016) stated that leadership could encourage different roles or OCB. In contrast, (Juniartha et al., 2017) explain that leadership contributes to OCB but is still low. It is because of the weak competence of employees in translating the direction of the leadership, so the extra role is reduced.

The role of OCB is a reflection of employees in building the company's image. They are moved to work with the orientation of increasing institutional performance. Moreover, they believe that when the organization provides performance, it will be a positive image. Studies from (Arianto, 2017), (Darto, 2014); (Fitriastuti. 2013); (Kartikaningdyah and Utami, 2017) indicated that employees who display extra-role behavior or OCB could improve performance. The higher the different roles or OCB, the higher the performance. Meanwhile, (Komalasari et al., 2009) stated that OCB has no relationship with performance. That is, performance is no longer determined by OCB.

The motivation of this research is, first, the phenomenon of objective conditions is interesting to analyze about the role of extra employees at the Makassar Main Harbormaster Office because the role of extra employees is colored by personal trust and leadership that it has an impact on employee performance. Furthermore, the results of previous studies on the relationship of trust with $\mathrm{OCB}$, leadership with $\mathrm{OCB}$, and the relationship of OCB with performance still lack explanations and debates on research results. Second, employee performance measurement at the Makassar Main Harbor Chief Office uses a work culture of "DAENG," which means D = Dedication; A=Accountable; E=Effective and efficient; $\mathrm{N}=$ Never give up; $\mathrm{G}=$ Goals. Therefore, employee performance indicators use the DAENG principle as well as a differentiator with previous studies.

Furthermore, the phenomenon of this objective condition will be approached with OCB theory. Thus, this article consists of several sections: a theoretical study, methodology; research result; discussion; last conclusion. 


\section{THEORETICAL REVIEW}

Relationship of Personal Trust with Performance: Confidence is the belief that employees have to do the right and productive work. As a characteristic of having good personal beliefs, it can be seen from the behavior of the ability to do work and always use opportunities to produce good and qualified performance. He is always happy to do real work and finish the job on time. The research of (Hajar, Lubis, 2018) found that personal trust can encourage employee performance. Employee performance will be obtained if there is personal confidence in doing work. In contrast to Eser's (2012) research, personal trust has no effect on performance. In other words, personal trust cannot contribute to creating performance. Therefore, personal trust can contribute to improving employee performance. Thus, the research hypothesis is:

\section{H1: There is a relationship of personal trust with employee performance.}

Relationship between Leadership and Employee Performance: Leadership is a skill in encouraging employees to do productive work. His attitude always displays the skills of movement, showing the best way, he is the moon and he is the sun who directly feels this so that employees are constantly moved to do work. Research by (Hajar et al., 2018) suggests that leadership can encourage employees to do good work. However, (Widyatmini and Hakim, 2008) found that leadership has a contribution in encouraging performance but is still low. Therefore, the hypotheses of this study are:

\section{H2: There is a relationship between leadership and employee performance.}

Relationship of Personal Trust with OCB: Self-confidence is a portrait where the individual has confidence that he has the knowledge, experience, skills in doing a job so that he does not hesitate to help others in doing the job. He always shows sympathetic and empathetic behaviors to co-worker's work in the form of an OCB role. OCB is aware of helping to finish other people's work. This awareness is born in building an atmosphere of coolness within the organization, and the organization will certainly produce performance. (Anggraini and Rahardjo's, 2016); (Rahayu, 2017) found that high trust can evoke the role of OCB. Research by (Anggraini and Rahardjo, 2016) states that only high-awareness employees can do extra work or OCB.

Meanwhile, Appelbaum et al. (2004) stated that personal trust contributes to OCB but is still weak. When trust is too high, which is not followed by sufficient competencies such as knowledge, experience, skills, and work awareness, it will reduce extra employee behavior. The approach used is quantitative by using SEM analysis.

In contrast to (Fitrijayanti et al., 2015), trust has no significant effect on OCB. That is, OCB is no longer determined by trust. Therefore, personal beliefs influence OCB. Then, the research hypothesis is:

H3: There is a personal trust relationship with $O C B$. 
Leadership Relationship with OCB: Usually, the leader's behavior shows inviting behavior, exudes happiness, and explains the flow of work clearly. Thus, employees as subordinates feel cool to do work. He always called his heart to help his friends to complete the work. Therefore, OCB is a form of reflection on the coolness enjoyed by employees from the behavior of leaders who are friendly to subordinates. (Indra et al., 2016) studies; (Kartini, 2019); (Napitupulu, 2018); (Tjahjono et al., 2018); (Yohannes and Supit, 2016) found that good leadership can encourage OCB.

In contrast, (Juniartha et al., 2017) find that good leadership may not result in low OCB. The better the leadership, the lower the OCB. It is because of the weak competence of employees in translating the direction of the leadership, so the extra role is reduced. Therefore, leadership influences OCB. So, the research hypothesis is:

\section{H4: There is a leadership relationship with OCB.}

OCB Relationship with Employee Performance: OCB can be interpreted as a reflection of a great willingness to help work on the work of others. Perhaps, OCB is born because there is awareness, where awareness arises. After all, there is empathy and love for work. Someone who has a love for work will love to work so that it will produce quality performance. The ability to do work voluntarily and with love can improve employee performance. Studies of (Arianto's, 2017); (Darto, 2014); (Fitriastuti, 2013); Kartikaningdyah and Utami (2017) state that employees who display extra-role behavior or OCB can improve performance. The higher the different roles or OCB, the higher the performance. They all use a quantitative approach with the type of survey research and plan-meanwhile, (Komalasari et al., 2009) stated that OCB has no relationship with performance. That is, performance is no longer determined by OCB. Therefore, OCB has a contribution to strengthening employee performance. Therefore, the research hypothesis is:

\section{H5: There is a relationship between $O C B$ and employee performance.}

\section{METHODS}

The purposive sampling technique became the sampling instrument. The aim is to ensure the accuracy of the information for Makassar Main Harbormaster Office employees who have an extra role of 54 people. The use of WarpPLS 7.0 will produce accurate information and test the research instrument's validity and reliability.

\section{RESULT OF THE RESEACH}

Men's involvement is quite dominant in realizing the SYAHDU program in the Makassar Main Harbormaster Office (70.4\%). In general, employees are dominated by those aged over 40 years by $42.6 \%$. Then, the education level is dominated by an undergraduate at $68.5 \%$ and high school at $22.2 \%$. Then, the dominant work experience of 20 and above 30 years is $37.0 \%$.

Three indicators show the goodness of the model in this study with a p-value of $\mathrm{P}<$ 0.001 . The model is said to be good because it is more than $50 \%$. Therefore, the data can be feasible to provide explanations and hypothesis testing. The average path coefficient is close 
to $50 \%$ because the Average path coefficient (APC) is 0.333 . Then, the average correlation of the determinants is above $50 \%$, as evidenced by the Average R-squared (ARS) $=0.653$. Furthermore, the correlation of several independent variables is above 50\%, where Average adjusted R-squared $(\mathrm{AARS})=0.635$. Therefore, from the three indicators, the model can be stated as good.

The variable profile contains information about indicators, factor loadings, and the average score of respondents' answers. The goal is to ensure accurate information, such as the table below.

Table 1. Profile of Personal Trust Variables (X1)

\begin{tabular}{clcc}
\hline No & \multicolumn{1}{c}{ Indicator } & Weight & Score Average \\
\hline 1 & Positive attitude towards oneself & 0.832 & 4.00 \\
2 & Positive attitude towards others & 0.924 & 3.88 \\
\hline
\end{tabular}

Source: 2021 research results

The indicator that has a factor loading that is greater or stronger in reflecting personal beliefs indicates a positive attitude towards others of 0.924 . A positive attitude towards other people who stand out is played by employees at the Makassar Main Harbormaster office. It means that there is an impression that employees always show cooperation and mutual trust to coolness at work. Not as a scary and annoying person (Fitrijayanti et al., 2015). Next, another indicator that can reflect personal confidence is followed, namely a positive attitude towards oneself. Therefore, positive attitudes towards self needs to be improved by Makassar Main Harbormaster Office employees. The personal trust variable is measured by two indicators: a positive attitude towards oneself and a positive attitude towards others. There are six items of questions in revealing the meaning of the two indicators.

Table 2. Leadership Variable Profile (X2)

\begin{tabular}{clccc}
\hline No & & Indicator & Weight & Score Average \\
\hline 1 & Personality & 0.647 & 4.04 \\
2 & Ability & 0.954 & 3.83 \\
3 & Capability & 0.894 & 4.16 \\
\hline
\end{tabular}

Source: 2021 research results

The indicator that has a stronger factor loading in reflecting the leadership at the Makassar Main Harbormaster Office is the ability indicator of 0.954. Leadership can build interrelationships or interactions between leaders, followers, and situations, especially in doing innovative things and in line with the SYAHDU movement. In contrast, the indicators that are still low are personality and capabilities, so that they need to be improved by the Makassar Main Harbormaster Office employees. The leadership variable is measured by three indicators, namely personality, ability, and capability. There are nine items of questions in revealing the meaning of the three indicators. 
Table 3. OCB Variable Profile (Y1)

\begin{tabular}{clcc}
\hline No & \multicolumn{1}{c}{ Indicator } & Weight & Score Average \\
\hline 1 & The will or desire to tolerate & 0.856 & 3.85 \\
2 & Employee voluntary behavior to help & 0.856 & 4.14 \\
& coworkers & 0.652 & 4.12 \\
\hline
\end{tabular}

Source: 2021 research results

The indicator with a greater factor loading in reflecting OCB is an indicator of voluntary employee behavior to help co-workers of 0.856 . That is a different role through volunteering to help co-workers or prevent work-related problems becomes important, especially in realizing the SYAHDU program at the Makassar Main Harbormaster Office. In contrast, other indicators are still low, namely the will or desire to tolerate and support from within a person. Three indicators measure the OCB variable: the will or desire to tolerate, voluntary employee behavior to help co-workers, and support from within a person. There are nine items of questions in revealing the meaning of the two indicators.

Table 4. Employee Performance Variable Profile (Y2)

\begin{tabular}{clcc}
\hline No & Indicator & Weight & Score Average \\
\hline 1 & Dedication & 0.618 & 4.98 \\
2 & Accountable & 0.801 & 4.04 \\
3 & Effective dan Efficient & 0.896 & 3.97 \\
4 & Never Give Up & 0.798 & 4.03 \\
5 & Goals & 0.641 & 4.09 \\
\hline
\end{tabular}

Source: 2021 research results

Indicators with a factor loading that is greater or stronger in reflecting employee performance are the Effective and Efficient indicators of 0.935. It means that employees can choose targets by using the right equipment to achieve a targeted result. While indicators that are still low in factor loading are Dedication, Accountable, Never Give Up, and Goals. Five indicators measure employee performance variables: dedication, accountability, effectiveness, efficiency, never give up, and Goals. There are 15 question items in revealing the meaning of the three indicators.

Table 5. Hypothesis Testing

\begin{tabular}{|c|c|c|c|c|}
\hline \multicolumn{2}{|c|}{ Relationship between Variables } & \multirow{2}{*}{$\begin{array}{c}\text { Coefficient } \\
\text { Direct } \\
\text { Influence }\end{array}$} & \multirow[b]{2}{*}{ p-value } & \multirow[b]{2}{*}{ Information } \\
\hline Independent & Dependent & & & \\
\hline Personal trust $(\mathrm{X} 1)$ & $\begin{array}{c}\text { Employee } \\
\text { performance (Y2) }\end{array}$ & $0.314^{*}$ & $<0.001$ & Significant \\
\hline Leadership (X2) & $\begin{array}{c}\text { Employee } \\
\text { performance (Y2) }\end{array}$ & 0.141 & 0.141 & Not significant \\
\hline Personal trust (X1) & OCB (Y1) & $0.415^{*}$ & $<0.001$ & Significant \\
\hline Leadership (X2) & OCB (Y1) & $0.467 *$ & $<0.001$ & Significant \\
\hline
\end{tabular}




\begin{tabular}{|c|c|c|c|c|c|}
\hline \multicolumn{2}{|l|}{ OCB (Y1) } & $\begin{array}{l}\text { Employee } \\
\text { ormance (Y2) }\end{array}$ & $0.329 *$ & $<0.001$ & Significant \\
\hline \multicolumn{6}{|c|}{ Independent $\rightarrow$ Mediation $\rightarrow$ Dependent } \\
\hline $\begin{array}{c}\text { Independent } \\
\text { Variable }\end{array}$ & $\begin{array}{c}\text { Mediation } \\
\text { Variable }\end{array}$ & $\begin{array}{l}\text { Dependent } \\
\text { Variable }\end{array}$ & $\begin{array}{l}\text { Indirect } \\
\text { Influence }\end{array}$ & p-value & Mediation Nature \\
\hline $\begin{array}{l}\text { Personal trust } \\
\text { (X1) }\end{array}$ & OCB (Y1) & $\begin{array}{c}\text { Employee } \\
\text { Performance } \\
\text { (Y2) }\end{array}$ & $0.136^{*}$ & 0.002 & $\begin{array}{c}\text { partial } \\
\text { mediation }\end{array}$ \\
\hline Leadership (X2) & OCB (Y1) & $\begin{array}{c}\text { Employee } \\
\text { Performance } \\
\text { (Y2) }\end{array}$ & $0.154 *$ & 0.009 & Mediation \\
\hline
\end{tabular}

Source: 2021 data processing results

Note: $*=$ significant at $=0.05$ (significant)

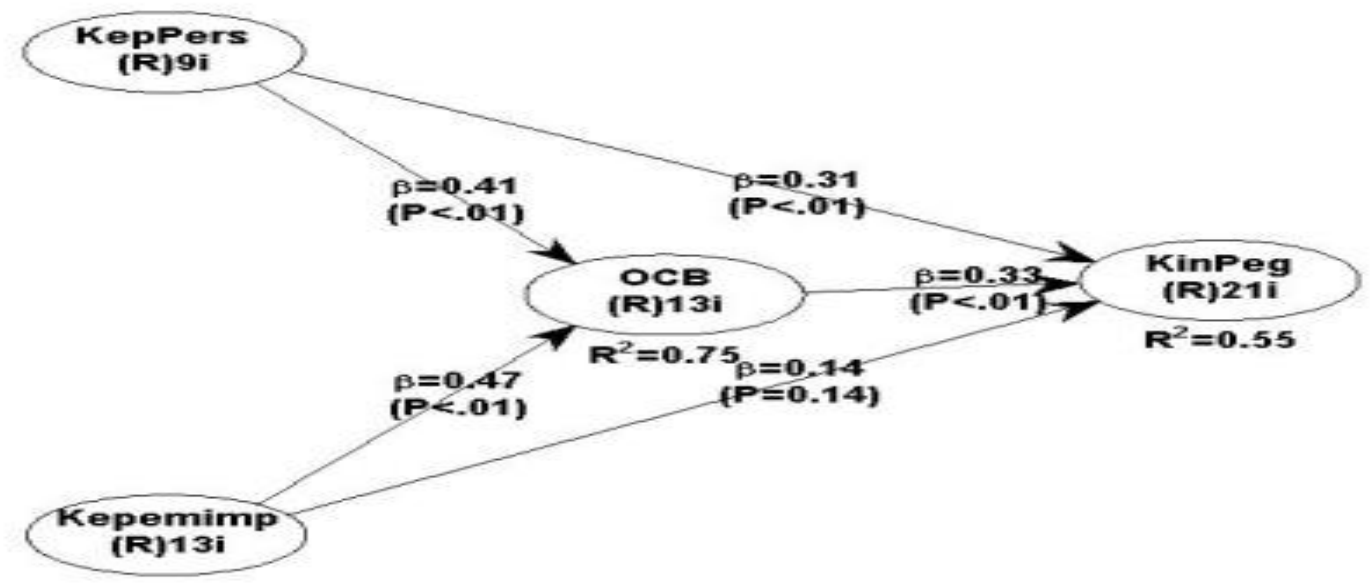

Figure 1. Research model

Information:

KepPres : Personal Trust

Kepemimp : Leadership

KinPeg : Employee Performance

Direct testing: All hypotheses proposed are acceptable because the p-value is less than 0.05 , except for the hypothesis that "leadership has a positive and significant effect on employee performance at the Makassar Main Harbormaster Office." rejected because the p-value is greater than 0.05 .

Indirect test: All proposed hypotheses can be accepted because the p-value is less than 0.05. The nature of mediation shows that the path coefficient value is lower than the coefficient without the OCB variable so that the OCB variable can be expressed as partial mediation. Furthermore, the path coefficient value is greater than the path coefficient without the OCB variable, and then the OCB variable can be expressed as mediation. 


\section{DISCUSSION}

The results of this study indicate that personal trust can encourage and be meaningful to the performance of employees at the Makassar Main Harbormaster Office. It can be interpreted that when personal trust is good, employee performance is getting better. The prominent positive attitude towards others indicates it by the employees of the Main Harbormaster Office. The positive attitude that employees play can reflect that employees have strong beliefs to produce good work. As proof that employees who have strong beliefs will cooperate in realizing the great ideals of the organization. They always believe that the work to be completed can provide benefits for themselves other than the organization. Therefore, it creates a pleasure to do the work so that they produce a good performance.

Because others accept his presence, an employee will have self-confidence or personal confidence. The combination of confidence and ability is an indicator of self-confidence in doing work. Therefore, employees who have self-confidence followed by genuine feelings will give birth to a confidence that the work can be completed in a timely and productive manner because someone who has the motivation and is willing to take risks is someone who has self-confidence that tends to be strong so that he will do the job professionally. Conversely, people who feel less capable and do not rely on their abilities will display less confident behaviors at work.

The SYAHDU program will be realized if it is framed with positive thoughts to be confident in his ability to perform well through DAENG champions. It is proven that the most prominent employee performance indicators are effective and efficient indicators without ignoring other indicators such as Dedication, Accountable, Never Give Up, and Goal indicators. That is the more confident about the ability to work, the better the employee's performance.

For the Main Harbormaster Office. Effective (Effective) means that every action has a result and is efficient. Meanwhile, efficient means appropriate quality, appropriate and timely, and carrying out tasks quickly, precisely, and carefully. Therefore, positive thoughts will strengthen confidence in the ability to realize the SYAHDU program effectively and efficiently. Dedication (dedication) by employees is to work with full dedication as a highly dedicated State Civil Apparatus (ASN). The spirit of service will be high if it is based on confidence in the ability of an employee to do a good job. In addition to having dedication, all forms of activities performed by employees must be accounted for. All behaviors that have employee work behavior within the Makassar Main Harbormaster Office are measurable and accounting. Employees who have confidence in their abilities will display measurable and accountable behavior.

Furthermore, the never-give-up indicator is attached to employees at work. That is behavior that is not easily discouraged in experiencing various obstacles, always working hard to achieve goals, thinking that obstacles or obstacles are always present in every activity that must be experienced. Moreover, the last indicator is a goal which is the ultimate goal to be achieved from a goal. Therefore, morale will be strong if high confidence in working so that the final goal will be achieved from a goal.

This study supports the research of (Hajar, Lubis, 2018), finding that personal trust can contribute to encouraging employee performance. The better the trust, the better the employee's performance. In contrast to (Eser's, 2012) research, personal trust does not affect performance. It means that personal beliefs no longer determine employee performance. 
Employee performance is also determined by leadership. Employee performance measurement indicators cause the difference with (Eser's, 2012) research. In this study, the DAENG principle in measuring employee performance is based on the reality at the Makassar Main Harbormaster Office.

The findings of this study that leadership cannot explain in encouraging employee performance. It means that leadership is not an important variable in encouraging performance at the Makassar Main Harbormaster Office. Even though respondents perceive that leadership is good. However, leadership does not have a significant influence on improving employee performance. Meanwhile, highlighted leadership behaviors, such as processing skills between relationships or interactions between leaders, followers, and the atmosphere, do not affect employee performance. Expertise or capacity is the background possessed by the leader over the level of expertise which can include ability, knowledge, and expertise both obtained officially, informally, or sourced from individual experience, which is useful for his leadership. From the respondent's answer, in the employee's personality, the DAENG jargon has been attached, which reflects improving performance. For them, the leadership ability factor is not the main determining factor in their work.

(Wahjosumidjo, 1987), quoted by (Pradana and Hamid, 2013), states that ideally, the behavior of leaders who have the capability can encourage performance. Capability is a psychological, mental state of a leader that reflects stability and full ability and responsibility to bear all the consequences of position and leadership. No matter how good a leader's capability is, it does not determine when working within the Makassar Main Harbormaster Office because they are already embedded in the minds of employees that the work, they always do is based on DAENG values.

They also realized that the personality of the leader within the Makassar Main Harbormaster Office was good. Personality (leader character) is more of radiance from the leader's personality, which concerns the character or nature attached. Leaders who have a good personality will be role models for subordinates and tend to be respected. For employees, the leader's personality is not a determining factor in completing work, but more importantly, it does not come out of DAENG's values.

The DAENG principle is a benchmark for employee performance within the Makassar Main Harbormaster Office in realizing the SYAHDU (educating portership) program. That is, the harbormaster educates intending to improve the safety and security of services. The form of guidance is to guide fishers and traditional ship owners to improve shipping safety and security aspects. In addition, the guidance provided specifically in terms of the certification process and the legal status of ships, includes increasing the skills and competencies of the crew of fishing boats and traditional vessels located in the Makassar Main Harbormaster Office working area.

This study does not support the research of (Hajar et al., 2018), which suggests that leadership can strengthen employee performance. When leadership is good, it can be ascertained that employee performance is good. However, (Widyatmini and Hakim, 2008) found that leadership has not fully encouraged employee performance. It may be good leadership, employee performance decreases. No matter how good the leadership is, if the employee's competence is lacking, the employee's performance will decrease or be below. The use of employee performance indicators causes this difference.

The results of this study indicate that personal trust can encourage OCB at the Makassar Main Harbormaster Office. It can be interpreted that good personal trust will 
encourage or strengthen employees' different roles or OCB. A positive attitude by employees causes high personal trust, the attitude of wanting to work voluntarily in helping other people's work. (Appelbaum et al., 2004) suggest that positive attitudes towards oneself and others are born of self-confidence. Because the different role of OCB reflects one's awareness of doing work in helping others, they like to do work and always take part in work that is considered difficult by others. Even employees will show a desire or will to be tolerant and voluntarily help co-workers. In addition, support from within a person will be strong because it is based on good personal beliefs.

It is proven that the stronger the positive attitude towards oneself, the better the different roles or OCB by employees. In the scope of the Makassar Main Harbormaster Office, extra behavior or OCB, which is reflected by the will or desire to tolerate and voluntary behavior of employees to help co-workers, is more dominant. So, these two indicators need to be maintained or improved again. Meanwhile, the attitude of support from within a person is still relatively low, so it needs improvement. Lack of self-confidence will lead to inappropriate work towards oneself and the organization (Eser, 2012). Employees with a good positive attitude will easily do the job and produce a good performance. Of course, the work environment will accept the works produced, and it is believed that the SYAHDU program will be carried out well. Therefore, employees who have a positive attitude towards others will make it easier for them to cooperate or move others because of the right attitude towards them.

Personal trust will encourage someone to take on a different role or OCB. The will or desire to tolerate and voluntary behavior of employees to help co-workers and an attitude of support from within a person reflects the different roles or OCB by employees. The higher the personal trust, the higher the different roles or OCB of an employee.

(Appelbaum et al., 2004) stated that when trust is too high, it must be followed by sufficient competencies such as friendly behavior towards others, knowledge, experience, skills, and work awareness will increase extra behavior by employees. Therefore, to realize the SYAHDU program, employees must have good personal trust and different roles or good OCB.

The study of (Anggraini and Rahardjo, 2016); (Rahayu, 2017) found that trust can strengthen the role of OCB. The trust of a good person can be believed to have a different role to get the job done the better. Moreover, this study does not support the research of (Appelbaum et al., 2004), which states that trust has a negative and significant effect on OCB. When trust is too high, which is not followed by sufficient competencies such as a positive attitude towards oneself, a positive attitude towards others, knowledge, experience, skills, and work awareness, it will reduce extra behavior by employees. Furthermore, it also does not support the research of (Fitrijayanti et al., 2015) that trust has no significant effect on OCB. That is, OCB is no longer determined by trust. Methodological differences can suspect differences in the results of this study with previous studies.

This study found that leadership has a positive and significant relationship with OCB. If the leadership is good, it can be ascertained that the different roles or OCB will be good. It is because the ability or capacity possessed by the leader is good, such as skills, patience, accuracy in work that comes from personal experience and accompanied by the radiance of an inviting leader, it tends to give birth to good OCB. Because there is an ability or capacity by the leadership so that employees are moved to take different roles or OCB such as the will or desire to tolerate and voluntary behavior of employees to help co-workers and an 
attitude of support from within, especially, therefore, it is necessary to voluntarily involve employees in realizing the SYAHDU program through leadership linkages with OCB.

Leadership does not only rely on ability but must be equipped with the capability or ability to motivate and support someone in extra-role activities or OCB. Leaders who always exude a cool character and invite them to work may be motivated to do extra OCB work because a good leader's personality can awaken subordinates to do work that is not their main task, such as OCB (Pradana and Hamid, 2013).

Leaders who have the ability, capability, and good personality will grow employees' desire in OCB. It is reflected by the behavior of the will or the desire to tolerate. The voluntary behavior of employees to help co-workers, and the attitude of support from within, especially. Therefore, leaders who have competence from the aspect of the ability, capability, and good personality will generate a desire to play a different role or OCB so that the SYAHDU program can be realized.

This research supports the research of (Indra et al., 2016); (Kartini, 2019); (Napitupulu, 2018); (Tjahjono et al., 2018); (Yohannes and Supit, 2016) found that good leadership can encourage the role of OCB. If the leadership is good, it will certainly encourage the different roles of good employees. This study does not support the research of (Juniartha et al., 2017), who found that good leadership, but the role of OCB decreased. The weak competence of employees in translating the direction of the leadership so that the different role is reduced. Methodological differences cause this difference.

This study found that OCB has a significant contribution in encouraging employee performance at the Makassar Main Harbormaster Office. That is, the better the different roles or OCB, the higher the employee's performance. The respondent's statement reinforces that OCB is reflected in the will or desire to tolerate and the voluntary behavior of employees to help co-workers, and the attitude of support from within is good. Indicators of willingness or desire to tolerate and voluntary behavior of employees to help co-workers are the most important indicators in reflecting OCB at the Makassar Main Harbormaster Office. Employee behavior such as helping others, talking about ideas for change so that co-workers stay enthusiastic about work and do not complain. Thus, OCB is the key to success. The motivation is to pursue achievement so that the DAENG principle is strong or good to measure employee performance.

Employee voluntary behavior to help co-workers is considered a charitable activity where an employee gives a voluntary role with high awareness to encourage performance. OCB behavior always puts forward the altruistic personality trait of having concern for the success of others who are not oriented to personal interests. Selfishness tends to be selfish, which is not in line with OCB principles. Therefore, the opportunity to achieve good performance can be obtained through the DAENG principles.

Voluntarily is a portrait of harmony within the organization. Employees who always display cooperative behavior with their co-workers will certainly provide extra services or OCB. Because for him helping is a characteristic of personal qualities. It is also intended to create a relationship that can enable it to be a good job. The SYAHDU or harbormaster program educates intending to improve service safety and security if the extra behavior (OCB) goes well and impacts employee performance.

In achieving success, employees can arouse the desire to help others born from support from within an employee. Extra role behavior or OCB likes to be challenged on the job. Employees who like to face challenges with work tend to dedicate themselves to helping 
other people's work. Employees who have extra behavior or OCB will differ from those who do not have extra behavior or OCB. Employees with an extra helping orientation believe they will be able to complete the job well because they think that all forms of work, they do always provide meaningful wisdom for themselves other than the organization.

This research supports (Arianto's, 2017); (Darto, 2014); (Fitriastuti, 2013); (Kartikaningdyah and Utami, 2017) state that employees who display extra-role behavior or OCB can improve performance. The higher the different roles or OCB, the higher the performance. Meanwhile, this study does not support the research of (Nasih and Prasetio, 2009) stated that OCB has no relationship with performance. That is, performance is no longer determined by OCB. Methodological differences cause this difference.

The results of this study indicate that personal trust can encourage employee performance through OCB. The higher the personal trust, the better the different roles or OCB and the better the employee's performance. It is because employees have strong beliefs so that they are handled well, especially in displaying extra behavior or OCB to produce a good performance. Of course, the employee will side with the work he faces because he has good self-confidence (Appelbaum et al., 2004). The attitude of looking at others is part of the desire to do extra work or OCB. It is proven that employees will show a desire or will to be tolerant and voluntarily help co-workers. In addition, support from within a person will be strong because it is based on good personal beliefs.

The strength of personal beliefs is reflected through the SYAHDU program. Because a pleasant attitude and can be trusted by others becomes a different role or OCB becomes good. Personal trust will encourage someone to take on a different role or OCB. The will or desire to tolerate and voluntary behavior of employees to help co-workers and an attitude of support from within a person reflects the different roles or OCB by employees. The higher the personal trust, the higher the different roles or OCB of an employee.

The role of OCB is characterized by the will or desire to tolerate and voluntary behavior of employees to help coworkers. Employee behavior is helping others, discussing ideas for change so that coworkers remain enthusiastic about work and do not complain so that employees get work performance. Usually, OCB behavior always puts forward the altruistic personality trait of having concern for the success and welfare of others and letting go of selfishness. It is because selfishness is contrary to the norm of different OCB roles. Therefore, the opportunity to achieve good performance can be obtained through the DAENG principles. When a community or person is served with love, it can be believed that it will perform well. Success can be measured by how much benefit is enjoyed by others. Therefore, the SYAHDU or harbormaster educational program to improve service safety and security will be achieved if extra behavior (OCB) goes well and impacts employee performance.

In achieving success, employees can arouse the desire to help others born from support from within an employee. Extra role behavior or OCB likes to be challenged on the job. When he helps others, he has social capital where he has long deposited his ability to be used in helping work outside his responsibilities. They consider that petrification is a desire to complete work that others have not completed. Because they work not financially oriented but socially oriented, only employees who have a sincere desire can perform different OCB roles to improve their performance.

This research supports the research of (Anggraini and Rahardjo, 2016); (Rahayu, 2017) finds that trust contributes to encouraging better OCB. When a person's level of trust 
is good, it can be believed that different roles to complete work tend to be high. At the same time, this research supports (Arianto's, 2017); (Darto, 2014); (Fitriastuti, 2013); (Kartikaningdyah and Utami, 2017) state that employees who display extra-role behavior or OCB can improve performance. The higher the different roles or OCB, the higher the performance.

The findings of this study explain that leadership contributes significantly to encouraging employee performance through OCB at the Makassar Main Harbormaster Office. The better the leadership, the better the different roles or OCB and the employee's performance. It is due to the ability or capacity possessed by the leader is good. Because there is an ability or capacity by the leadership so that employees are moved or desire to do different roles or OCB, leadership must be equipped with the capability or ability to motivate and support someone in extra-role activities or OCB. That is, psychologically, a leader can provide shade in inviting subordinates to do extra work so that an employee grows a desire to do extra-role activities or OCB. In addition, a leader must have a good personal character so employees' desire will grow to perform different roles or OCB.

The ability, capability, and good personality will grow the desire of employees in OCB. Reflected by the behavior of the will or the desire is to tolerate. The voluntary behavior of employees to help co-workers, and the attitude of support from within, especially. Therefore, leaders who have competence from the aspect of the ability, capability, and good personality will generate a desire to play a different role or OCB so that the SYAHDU program can be realized.

Employees who have extra behavior or OCB will differ from those who do not have extra behavior or OCB. Besides they have helpful behavior, they also have creativity in their work. Unique creativity, whether visible or not, such as ideas, solutions, concepts can be categorized as creative employees. Their ideas and concepts complement the ease of implementing the SYAHDU program at the Makassar Main Harbormaster Office. Psychologically, employees who have a desire to perform different roles will display good performance. It is proven that the role of OCB can improve performance through the DAENG principle. Therefore, to realize the SYAHDU program, one must have a good leader so that the employee desires to grow to do OCB and perform well.

This study supports the research of (Indra et al., 2016); (Kartini, 2019); (Napitupulu, 2018); (Tjahjono et al., 2018); (Yohannes and Supit, 2016) found that leadership can contribute significantly to OCB. Because, when leadership is good, it can be ascertained that the role of extra employees is good too. Furthermore, at the same time, support (Arianto's, 2017); (Darto, 2014); (Fitriastuti, 2013); (Kartikaningdyah and Utami, 2017) state that employees who display extra-role behavior or OCB can improve performance. The higher the different roles or $\mathrm{OCB}$, the higher the performance.

\section{CONCLUSION}

This research aims to investigate the improvement of employee performance with the role of OCB in mediating the relationship of personal trust and leadership. Personal trust can encourage employee performance at the Makassar Main Harbormaster Office. Then, leadership is not able to explain the performance of employees. That is, leadership has no influence or is no longer determined by leadership. Furthermore, personal trust can contribute to encouraging the role of OCB. Leadership can push well against OCB. 
Likewise, OCB has a significant role in encouraging employee performance. Then, personal trust can strengthen employee performance through OCB. Moreover, lastly, good leadership can certainly encourage employee performance through OCB.

The limitations of this research are still in the scope of the Makassar Harbormaster Main Office so that the object of future research can be expanded in scope.

\section{REFERENCES}

Anggraini, M. M., dan Rahardjo, M. (2016). Peran Keadilan Prosedural, Kepercayaan, Kepuasan Kerja Dan Komitmen Organisasi Dalam Meningkatkan Organizational Citizenship Behavior (OCB) (Studi pada Karyawan PDAM Kabupaten Demak). Diponegoro Journal of Management, 5(4), 1-14.

Appelbaum, S., Bartolomucci, N., Beaumier, E., Boulanger, J., Corrigan, R., Doré, I., Serroni, C. (2004). Organizational citizenship behavior: A case study of culture, leadership and trust. Management Decision, 42(1), 13-40.

Arianto, D. (2017). Pengaruh Kepuasan Kerja Terhadap Kinerja Karyawan Melalui Organizational Citizenship Behavior Sebagai Variabel Intervening (Studi Pada Staff Pt Kepuh Kencana Arum Mojokerto. Jurnal Ilmu Manajemen (JIM), 5(3).

Damaryanthi, A. A. I., dan Dewi, A. A. S. K. (2016). Pengaruh Kecerdasan Emosional, Komitmen Organisasi, Dan Organizational Citizenship Behavior Terhadap Kinerja Pegawai Feb. E-Jurnal Manajemen Unud, 5(2), 790-820.

Darto, M. (2014). Peran Organizational Citizenship Behavior (OCB) Dalam Peningkatan Kinerja Individu Di Sektor Publik: Sebuah Analisis Teoritis Dan Empiris. Jurnal Borneo Administrator, 10(1), 10-34.

Eser, Z. (2012). Inter-organizational trust in franchise relationships and the performance outcomes The case of fast-food restaurants in Turkey. International Journal of Contemporary Hospitality Management, 24(5), 774-790.

Fitriastuti, T. (2013). Pengaruh Kecerdasan Emosional, Komitmen Organisasi, Dan Organizational Citizenship Behavior Terhadap Kinerja Karyawan. Jurnal Dinamika Manajemen, 4(2), 103-114.

Fitrijayanti, D., Asmony, T., dan Suprayetno, J. (2015). Pengaruh Quality Of Work Life (Qwl) Dan Kepercayaan Pada Pimpinan Terhadap Organizational Citizenship Behavior (Ocb) Melalui Komitmen Organisasional (Studi Pada Balai Latihan Kerja Pemerintah Sepulau Lombok). URNAL MAGISTER MANAJEMEN UNIVERSITAS MATARAM, (September), 1-14.

Hajar, S., Lubis, A. R., dan Lubis, P. H. (2018). Pengaruh Perilaku Kepemimpinan Dan Kepercayaan Terhadap Kinerja Dinas Sosial Tenaga Kerja Dan Transmigrasi Kabupaten Aceh Barat. Jurnal Magister Manajemen, Vol 2(1), 46-57.

Indra, B. A., Azis, I., dan Kornelius, Y. (2016). Pengaruh gaya kepemimpinan transformasional, transaksional, kepuasan kerja terhadap OCB karyawan PT.konstrindo putera perkasa. Jurnal Ilmu Manajemen Universitas Tadulako, 2(1), 27-38.

Juniartha, I., Wardana, I., dan Putra, M. (2017). Pengaruh Kepemimpinan Transformasional Terhadap Organizational Citizenship Behavior (OCB) Melalui Mediasi Kepercayaan Kepada Atasan Dan Kepuasan Kerja (Studi pada Pegawai Tetap Balai Diklat Industri 
Kementerian Perindustrian Republik Indonesia). Buletin Studi Ekonomi, 21(2), 181196.

Kartikaningdyah, E., dan Utami, N. K. (2017). Kinerja Karyawan Dengan Variabel Mediasi Organizational Citizenship Behavior ( OCB ). Journal of Business Administration, 1(2), 256-269.

Kartini, I. (2019). Pengaruh Gaya Kepemimpinan Terhadap Organizational Citizenship Behaviour (Ocb) Di Politeknik Lp3I Jakarta Kampus Jakarta Utara. Jurnal Lentera Bisnis, 6(1), 75.

Komalasari, P. T., Moh. Nasih, dan Teguh Prasetio. (2009). Pengaruh Public Service Motivation Dan Organizational Citizenship Behavior Terhadap Kinerja Organisasi Pemerintahan. Jurnal Manajemen Teori Dan Terapan, 2(2), 128-141.

Lubis, M. S. (2015). Pengaruh Iklim Organisasi Dan Komitmen Organisasi Terhadap Pembentukan Organizational Citizenship Behavior (Ocb) Karyawan Dalam Rangka Peningkatan Kinerja. E-Jurnal Apresiasi Ekonomi, 3(2), 75 - 84.

Napitupulu, D. (2018). Pengaruh Kepemimpinan Transformasional Dan Komitmen Organisasi Terhadap Organizational Citizenship Behavior (OCB) (Studi Pada Perawat Rumah Sakit Puri Husada Di Tembilahan). Jom Fisip, 5, 1-15.

Oemar, Y. (2013). Pengaruh Budaya Organisasi, Kemampuan Kerja dan Komitmen Organisasi terhadap Organizational Citizenship Behavior (OCB) Pegawai pada BAPPEDA Kota Pekanbaru. Jurnal Aplikasi Manajemen, 11(66), 65-76.

Pradana, M. A., dan Hamid, D. (2013). Pengaruh gaya kepemimpinan transformasional dan transaksional terhadap kinerja karyawan (Studi Pada Karyawan Tetap PT. Mustika Bahana Jaya, Lumajang). Jurnal Administrasi Bisnis, 4(1), 1-11.

Rahayu, E. S. (2017). Pengaruh Budaya Kerja, Integritas Dan Kepercayaan Terhadap Organizational Citizenship Behavior (OCB) Pada Dosen Universitas Negeri Jakarta. Jurnal Ilmiah Econosains, 15(1).

Tjahjono, H. K., Prasetyo, F., dan Palupi, M. (2018). Kepemimpinan Transformasional Pada Organizational Citizenship Behavior Dan Komitmen Afektif. Jurnal Manajemen Dan Pemasaran Jasa, 11(2), 217-232.

Widyatmini, dan Hakim, L. (2008). Hubungan Kepemimpinan, Kompensasi Dan Kompetensi Terhadap Kinerja Pegawai Dinas Kesehatan Kota Depok. Jurnal Ekonomi Bisnis No., 13(2), 163-171.

Yohannes, I., dan Supit, I. (2016). Pengaruh Gaya Kepemimpinan Transformasional Terhadap Komitmen Organisasional Dan Organizational Citizenship Behavior Yang Dimediasi Oleh Kepuasan Kerja. Jurnal Riset Bisnis Dan Manajemen, 4(3), 351-368. 